\title{
29. SELECTED NEOGENE CALCAREOUS NANNOFOSSIL INDEX TAXA OF THE SOUTHERN OCEAN: BIOCHRONOLOGY, BIOMETRICS, AND PALEOCEANOGRAPHY1
}

\author{
Wuchang Wei ${ }^{2,3}$ and Sherwood W. Wise, Jr. ${ }^{2}$
}

\begin{abstract}
Selected Neogene calcareous nannofossil datums have been determined in seven Ocean Drilling Program (ODP) sites ranging from $50^{\circ}$ to $65^{\circ} \mathrm{S}$ latitude on the Kerguelen Plateau (southern Indian Ocean) and Maud Rise (Weddell Sea). Our data reveal that the first occurrence (FO) of Calcidiscus leptoporus/Calcidiscus macintyrei is not a useful event on Maud Rise, but it is an excellent biostratigraphic marker on the Kerguelen Plateau with an age of about 18.1 $\mathrm{Ma}$. The last occurrence (LO) of Cyclicargolithus floridanus is also a useful datum (11.1-12.2 Ma) in the southern high latitudes. The FO of Reticulofenestra perplexa is consistently younger toward the lower latitudes (14.4 Ma at $65^{\circ} \mathrm{S}$ to $12.3 \mathrm{Ma}$ at $55^{\circ} \mathrm{S}$ ) and the age vs. latitude curve established can be used to estimate the age of this datum in different latitudes of the Southern Ocean.

A biometric study of Reticulofenestra perplexa for Sites 744 and 748 on the Kerguelen Plateau shows that most specimens range from 5 to $8 \mu \mathrm{m}$ in length, similar to those of the topotypic material of $R$. perplexa from Deep Sea Drilling Project (DSDP) Site 265. The mean size change of the species through time in the 13-8 Ma interval is not useful for biostratigraphy because there is not a clear trend.

Abundance changes of Reticulofenestra perplexa relative to Coccolithus pelagicus have been studied in six ODP sites $\left(50^{\circ}\right.$ to $65^{\circ} \mathrm{S}$ latitude) in the Southern Ocean. The patterns of abundance changes are generally similar at these southern high-latitude sites, and the abundance fluctuations in the 10-8 Ma interval can be interpreted as reflections of alternating warm and cool events during that time interval.

Because of its ability to tolerate and even thrive in cold surface waters, $R$. perplexa significantly influenced the carbonate-compensation depth (CCD) in the Southern Ocean during the Miocene. The disappearance of this species coupled with the establishment of the Polar Front Zone during the late Miocene-early Pliocene glaciations of East and West Antarctica left the high-latitude Southern Ocean virtually devoid of nannofossil ooze deposition.
\end{abstract}

\section{INTRODUCTION}

It is well known that the stratigraphic ranges of many calcareous nannofossil species are truncated toward the higher latitudes and that many species simply could not live in the high latitudes. On the other hand, some cool- or coldwater species did not thrive in the low latitudes, and their stratigraphic ranges may become shorter toward lower latitudes. The diachroneity of species across latitudes is most distinct for the Neogene, when the latitudinal thermal gradients greatly increased as a result of long-term Cenozoic global cooling.

Until very recently, only fragmentary Neogene sedimentary sections have been recovered from the Southern Ocean and virtually no magnetostratigraphy has been available for these sections. Consequently, it has been difficult to determine the degree of synchroneity or diachroneity of nannofossil datums in these high latitudes. To help fill a critical regional gap in global paleoceanographic and paleoclimatic reconstructions, Ocean Drilling Program (ODP) Leg 113 (JanuaryMarch, 1987) in the Weddell Sea and Legs 119 (DecemberFebruary, 1988) and 120 (February-April, 1988) in the southern Indian Ocean recovered fairly long and complete Neogene sequences at a number of sites (Fig. 1). Detailed biostratigraphies and magnetostratigraphies have been established in these sedimentary sequences. This offers an unprecedented opportunity to evaluate the synchroneity or diachroneity of

\footnotetext{
${ }^{1}$ Wise, S. W., Jr., Schlich, R., et al., 1992. Proc. ODP, Sci. Results, 120: College Station, TX (Ocean Drilling Program).

2 Department of Geology, Florida State University, Tallahassee, FL 32306, U.S.A.

${ }^{3}$ Current address: Scripps Institution of Oceanography, University of California, San Diego, La Jolla, CA 92093, U.S.A.
}

the nannofossil datums in the Southern Ocean and to trace the evolution of climate through time.

The first objective of this study is to synthesize the biomagnetostratigraphic data from Legs 113,119 , and 120 for selected Neogene nannofossil species to determine the synchroneity or diachroneity of key datums. Following this, we examine the application of biometrics to the refinement of the stratigraphy. Last, we investigate the response of certain members of the nannofossil assemblages to paleoceanographic change during the late Neogene. The latter two objectives are explained in more detail below.

One of the most important Neogene nannofossil species in the Southern Ocean is Reticulofenestra perplexa (Burns) Wise, a senior synonym of Dictyococcites antarcticus Haq (see detailed discussions by Wise, 1983, and Wei, 1990). The biometric study by Backman (1980) indicates that the mean size change of $R$. perplexa is useful for locating the Miocene/ Pliocene boundary. As Backman (1980) used samples from different localities to plot the mean size change of $R$. perplexa through the Miocene, difficulties in age correlation among different sites may have complicated the interpretation of his results. Thus, the second objective of this study is to analyze $R$. perplexa in two continuous sequences at Sites 744 (Southern Kerguelen Plateau) and 748 (Central Kerguelen Plateau) to see whether the mean size change through time is useful for biostratigraphy in the Southern Ocean.

Calcareous nannoplankton live in the photic zone of oceanic waters and are therefore subject to direct climatic control (Siesser and Haq, 1987). McIntyre (1967), McIntyre and Bé (1967), and McIntyre et al. (1970) have shown that nannoplankton species are restricted to waters of definite temperature ranges. Paleobiogeographic studies also reveal that calcareous nannofossil assemblages are latitudinally differentiated, which is believed to be related to latitudinal thermal 


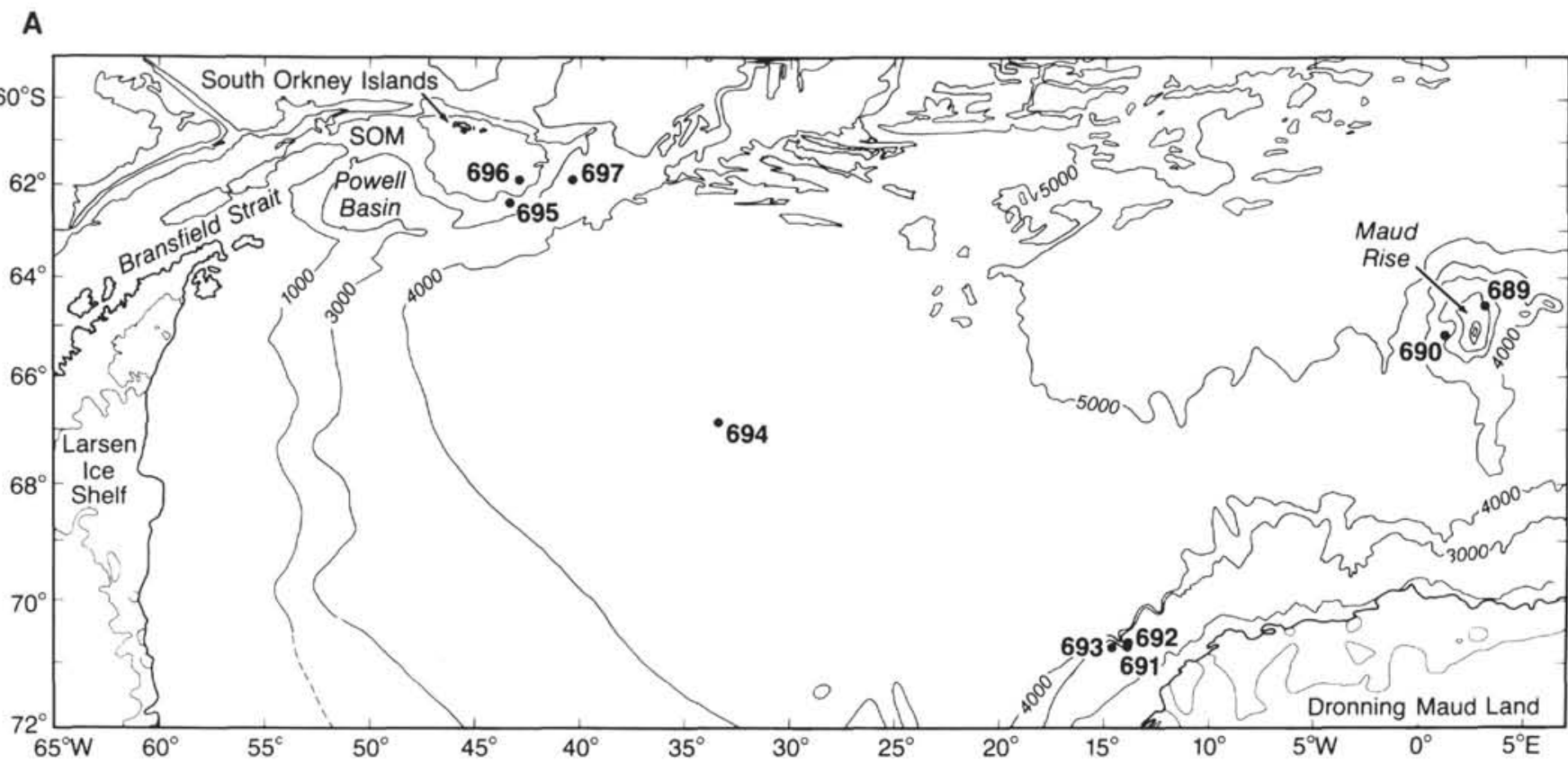

B

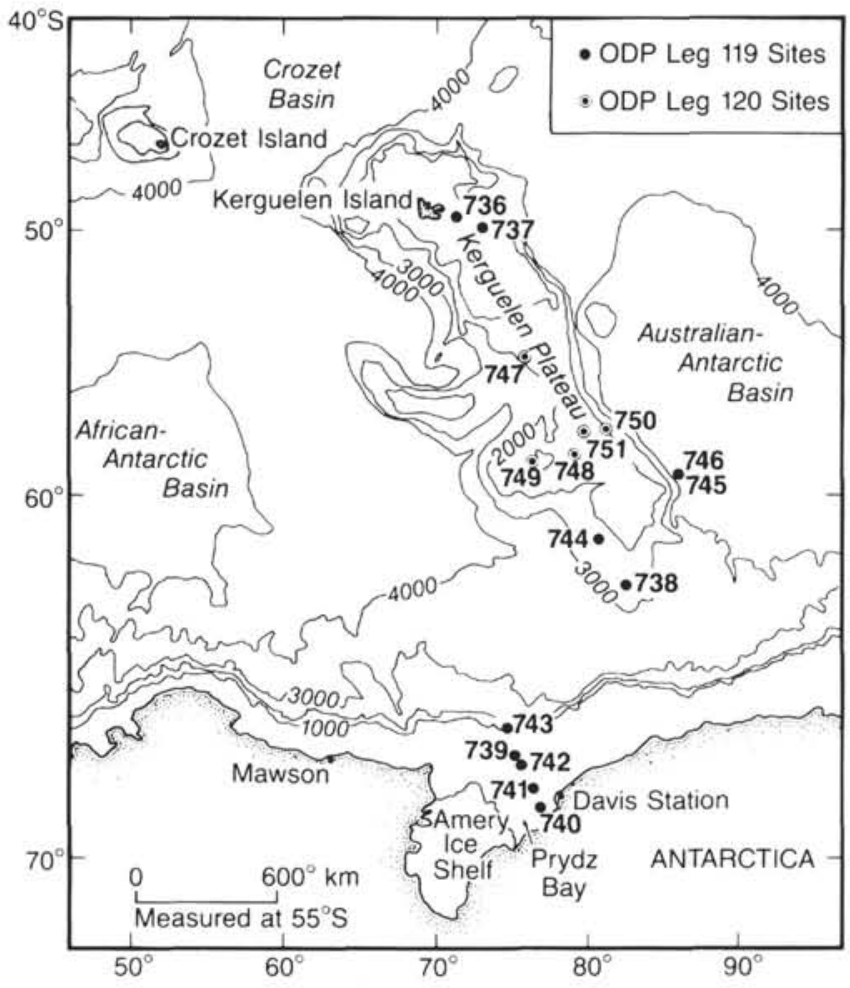

Figure 1. A. Locations of Leg 113 sites in the Weddell Sea. B. Locations of Leg 119 and 120 sites in the southern Indian Ocean.

gradients (e.g., Haq and Lohmann, 1976; Haq et al., 1977; Roth and Krumbach, 1986; Wei and Wise, 1990a).

It has been noted previously that Reticulofenestra perplexa is most abundant in the southern high latitudes (Haq, 1980; Wise, 1983; Wei and Wise, 1990b; Wei and Thierstein, 1991). This species was found at ODP Site $693\left(71^{\circ} \mathrm{S}\right)$ in the Weddell Sea (Barker, Kennett, et al., 1988) and at ODP Site $739\left(67^{\circ} \mathrm{S}\right)$ in Prydz Bay (Antarctica) (Wei and Thierstein, 1991). Reticulofenestra perplexa, therefore, represents the cold-water end member of Miocene calcareous nannofossil assemblages. Haq (1980) reported that three distinct abundance peaks of $R$. perplexa coincided approximately with isotopically determined coolings of the Southern Hemisphere, and he suggested that the fluctuations of the species may reflect waxes and 
Table 1. Locations and water depths of sites studied.

\begin{tabular}{|c|c|c|c|}
\hline Site & Latitude & Longitude & $\begin{array}{l}\text { Water } \\
\text { depth } \\
\text { (mbsf) }\end{array}$ \\
\hline 689 & $64^{\circ} 31.009^{\prime} \mathrm{S}$ & $03^{\circ} 05.996^{\prime} \mathrm{E}$ & 2080 \\
\hline 690 & $65^{\circ} 9.629^{\prime} \mathrm{S}$ & $01^{\circ} 12.296^{\prime} \mathrm{E}$ & 2914 \\
\hline 736 & $49^{\circ} 24.121^{\prime} \mathrm{S}$ & $71^{\circ} 39.611^{\prime} \mathrm{E}$ & 629 \\
\hline 737 & $50^{\circ} 13.660^{\prime} \mathrm{S}$ & $73^{\circ} 01.950^{\prime} \mathrm{E}$ & 564 \\
\hline 744 & $61^{\circ} 13.656^{\prime} \mathrm{S}$ & $80^{\circ} 35.463^{\prime} \mathrm{E}$ & 2307 \\
\hline 747 & $54^{\circ} 48.68^{\prime} \mathrm{S}$ & $76^{\circ} 47.64^{\prime} \mathrm{E}$ & 1695 \\
\hline 748 & $58^{\circ} 26.45^{\prime} \mathrm{S}$ & $78^{\circ} 58.89^{\prime} \mathrm{E}$ & 1287 \\
\hline 751 & $57^{\circ} 43.56^{\prime} \mathrm{S}$ & $79^{\circ} 48.89^{\prime} \mathrm{E}$ & 1633 \\
\hline
\end{tabular}

wanes of the antarctic ice sheet. During the study of subantarctic Quaternary calcareous nannofossils, Geitzenauer (1969) noted that Coccolithus pelagicus dominates the nannofossil assemblages in samples where warm-water radiolarian species are most abundant. This is reasonable because modern $C$. pelagicus is most abundant in waters of $6^{\circ}-14^{\circ} \mathrm{C}$ (McIntyre and Bé, 1967). When waters of a similar temperature range expanded to the subantarctic during warmer Quaternary intervals, $C$. pelagicus became abundant. Consequently, it is possible to use the abundance change of $R$. perplexa relative to $C$. pelagicus as a paleotemperature change indicator, that is, increasing abundance of $R$. perplexa relative to $C$. pelagicus indicates decreasing water temperatures, and decreasing abundance of $R$. perplexa suggests increasing water temperatures.

The third objective of this study, therefore, is to examine the abundance change of $R$. perplexa relative to $C$. pelagicus for a half dozen ODP sites ranging from $50^{\circ}$ to $65^{\circ} \mathrm{S}$ latitude to determine relative temperature changes in the surface waters of the Southern Ocean during the middle and late Miocene. This is especially useful as no oxygen isotopic data of Neogene planktonic foraminifers are available from the southern high latitudes.

\section{MATERIALS AND METHODS}

Samples from Sites 689 (Weddell Sea), 737, 744, 747, 748, and 751 (southern Indian Ocean) were analyzed in this study (Fig. 1 and Table 1). Biostratigraphic and magnetostratigraphic information are available for the Neogene interval concerned at all the above sites except for Site 737, where only biostratigraphy is available. Age assignments of the samples (Appendix) are based on sedimentation rate curves constructed using biomagnetochronology for Sites 689 (Gersonde et al., 1990), 744 (Barron et al., 1991a), and 747, 748, and 751 (Harwood et al., this volume); and using biochronology for Site 737 (Barron et al., 1991a). This is done by assigning numerical ages to subchron boundaries according to the time scale of Berggren et al. (1985) and assuming a uniform sedimentation rate within each subchron. Information on selected calcareous nannofossil datum levels are taken from Wei and Wise (1990b) for Sites 689 and 690, Wei and Thierstein (1991) for Sites 737 and 744, and Wei and Wise (this volume) for Sites 747,748 , and 751 .

For the biometric study of Reticulofenestra perplexa, the first 30 or more well preserved specimens of the species encountered along random traverses of each smear slide were measured on a Panasonic monitor screen connected to a Panasonic video camera mounted on a Zeiss Photomicroscope III. Magnification of the screen images was determined by measuring a micrometer on the screen. The measurement error is estimated to be about $0.3 \mu \mathrm{m}$. Analyzing 30 or more specimens allows an estimation of the population mean with a known confidence level:

$$
X \pm Z_{\alpha i 2} /(S / \sqrt{N})
$$

where $X=$ the mean of the measurements,

$S=$ the standard deviation of the measurements,

$N=$ the numbers of measurements, and

$Z_{\alpha / 2}=1.96$ for a $95 \%$ confidence interval (McClave and Dietrich, 1982).

The abundance of Reticulofenestra perplexa relative to Coccolithus pelagicus was determined by counting 200 or more specimens of the two species along random traverses of each slide. As stated above, the temperature preference of $R$. perplexa relative to $C$. pelagicus is reasonably well known. The collection of such abundance data should simplify interpretation of the data in terms of paleotemperature changes. On the other hand, the temperature preference of $C$.pelagicus relative to other nannofossil species, such as Cyclicargolithus floridanus, Calcidiscus leptoporus, Calcidiscus macintyrei, and Reticulofenestra gelida, is poorly known in the Southern Ocean. The distribution patterns of $C$. pelagicus in the subarctic is also problematic in terms of water temperatures (Gard, 1988). Thus, we make no attempt to determine the ratio of $C$. pelagicus vs. these or similar taxa, as some investigators have done (e.g., Raffi and Rio, 1981).

\section{BIOCHRONOLOGY}

There are considerable difficulties in using light microscopy to distinguish Calcidiscus leptoporus from Calcidiscus macintyrei consistently, and the first occurrence (FO) of these two species are virtually the same (Perch-Nielsen, 1985). Therefore, the FO of this group bears some discussion.

Okada and Bukry (1980) do not specify the marker species for the CN3/CN4 boundary, but refer instead to Bukry (1973 and 1975). Bukry (1973) used the LO of Helicosphaera ampliaperta to define this boundary, whereas Bukry (1975) used the FO of $C$. macintyrei instead. As $H$. ampliaperta is generally rare or absent in deep sea sediments, the FO of $C$. macintyrei has been widely used for the $\mathrm{CN} 3 / \mathrm{CN} 4$ boundary (Perch-Nielsen, 1985), which has been taken to be equivalent of the NN4/NN5 zonal boundary (Berggren et al., 1985; Martini and Müller, 1986). Berggren et al. (1985) assigned an age of $16.2 \mathrm{Ma}$ to the $\mathrm{CN} 3 / \mathrm{CN} 4$ boundary.

Calcidiscus leptoporus/C. macintyrei have a rare and sporadic occurrence at Site 689 and are virtually absent at ODP Site 690 , two extremely high-latitude sites $\left(65^{\circ} \mathrm{S}\right)$ in the Weddell Sea. The FO of C. leptoporus/C. macintyrei at Site 689 was recorded between Samples 113-689B-7H-1, 29-31 $\mathrm{cm}$, and $-7 \mathrm{H}-2,29 \mathrm{~cm}$ (Wei and Wise, 1990b), which has an age of about $14.2 \mathrm{Ma}$ according to biomagnetochronology (Gersonde et al., 1990). Because of the sporadic occurrence or virtual absence of $C$. leptoporus/C. macintyrei at these sites, the apparent FO of these taxa must be unreliable and considerably younger at such latitudes than at lower latitude sites.

The FO of Calcidiscus leptoporus/C. macintyrei at Site 744 on the Southern Kerguelen Plateau was recorded between Samples 119-744B-9H-6, 118-119 cm, and -9H-CC (Wei and Thierstein, 1991), and has a well-constrained age of $18.2 \mathrm{Ma}$ by biomagnetochronology (Barron et al., 1991a). On the central Kerguelen Plateau, the datum was recognized between Samples 120-747A-11H-1, 58-62 cm, and - $11 \mathrm{H}-2,58-62 \mathrm{~cm}$, at Site 747; between Samples 120-748B-6H-3, 58-62 cm, and $-6 \mathrm{H}-4,58-62 \mathrm{~cm}$, at Site 748; and between Samples 120-751A$16 \mathrm{H}-7,63-65 \mathrm{~cm}$, and $-17 \mathrm{H}-1,22-25 \mathrm{~cm}$, at Site 751 (Wei and Wise, this volume). According to the sedimentation rate curves constructed by Harwood et al. (this volume), the FO of C. leptoporus/C. macintyrei has ages of $18.0,18.1$, and 18.1 


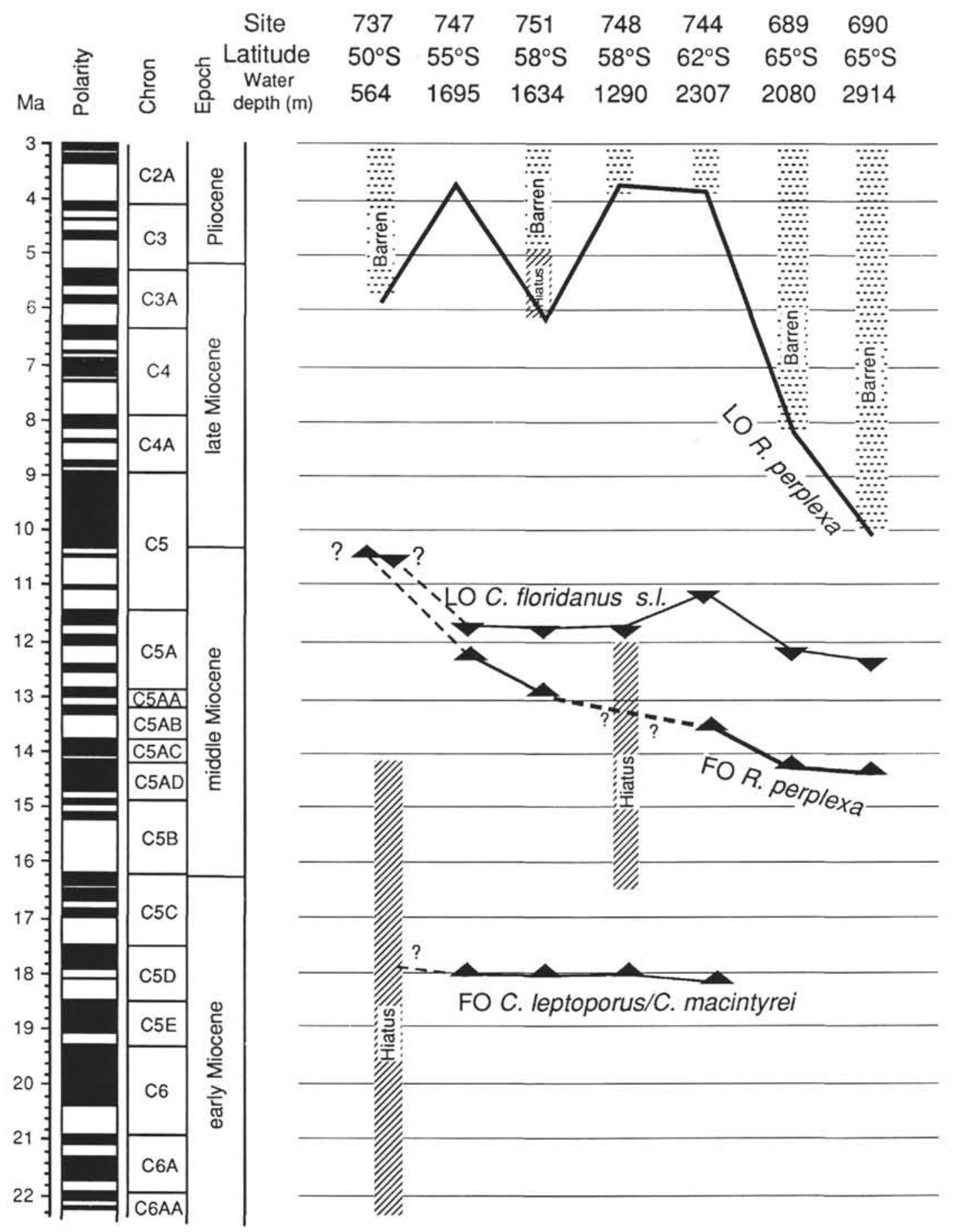

Figure 2. Ages of selected Neogene calcareous nannofossil datums at different latitudes in the Southern Ocean. Information on the datum levels are taken from Wei and Wise (1990b) for Sites 689 and 690, Wei and Thierstein (1991) for Sites 737 and 744, and Wei and Wise (this volume) for Sites 747, 748, and 751 (see "Material and Methods" section, this chapter, for details).

Ma at Sites 747,748 , and 751 , respectively. These ages are remarkably consistent for the Central and Southern Kerguelen Plateau sites (Fig. 2). At the Northern Kerguelen site (737), a disconformity encompasses the 14-24 Ma interval, prohibiting the determination of the FO of $C$. leptoporus/C. macintyrei.

Elsewhere, the reported FO of $C$. leptoporus/C. macintyrei does not appear to be very consistent. For example, Lohmann (1986) reported it in NN2 (ca. 19-23 Ma) at DSDP Sites 588 and 590, in NN5 (ca. 15-16 Ma) at DSDP Site 591, and in NN3 (ca. 17-18 Ma) at DSDP Sites 592 and 593, all in the southwestern Pacific. Knüttel (1986) recorded this event at the $\mathrm{CN} 1 / \mathrm{CN} 2$ zonal boundary (ca. $17 \mathrm{Ma}$ ) at DSDP Site 597 in the Central Pacific Ocean. Knappertsbusch (1989) reported an age of about $22.4 \mathrm{Ma}$ for the FO of $C$. leptoporus/C. macintyrei at DSDP Site 608 in the North Atlantic Ocean, although the possibility of downhole contamination has been suggested for 
this sequence (J. Backman, pers. comm., 1989). It should be noted that the sites mentioned above have no magnetostratigraphy and the estimated ages may be subject to error due to diachroneity of other nannofossil datums used to zone the sediments. At another North Atlantic site (563), the correlation of $C$. leptoporus/C. macintyrei with magnetochronology resulted in an age of $17.4 \mathrm{Ma}$ (Parker et al., 1985; Khan et al., 1985). The $16.2 \mathrm{Ma}$ age assigned to the $\mathrm{CN} 3 / \mathrm{CN} 4$ boundary in the Berggren et al. (1985) time scale is probably too young in most places. Currently available data reveal that there is not a clear latitudinal trend of time transgression for the FO of $C$. leptoporus/C. macintyrei. Water temperature is probably not the major factor controlling the FO of these species. It is clear, however, that the FO of $C$. leptoporus/C. macintyrei is virtually synchronous $(18.1 \pm 0.2 \mathrm{Ma})$ across the Kerguelen Plateau, and it provides an excellent biostratigraphic marker in this region.

\section{LO of Cyclicargolithus floridanus}

The LO of Cyclicargolithus floridanus is a secondary marker for the $\mathrm{CN} 5 \mathrm{a} / \mathrm{CN} 5 \mathrm{~b}$ (NN6/NN7) boundary in the zonation of Okada and Bukry (1980). Berggren et al. (1985) assigned an age of 13.1 Ma for this boundary although biomagnetostratigraphic data were not cited for the LO of $C$. floridanus. At North Atlantic DSDP Site 563 (mid latitude), the LO of $C$. floridanus falls between Samples 82-563-6-1, 60-62 cm, and -6-2, 60-62 $\mathrm{cm}$ (Parker et al., 1985), which is within Subchron C5AN at about 11.6 Ma (Khan et al., 1985; Miller et al., 1985). Ages given for the LO of $C$. floridanus at other localities are quite different. For instance, Lohmann (1986) reported the LO of $C$. floridanus in NN6 (ca. $14 \mathrm{Ma}$ ) at DSDP Sites 588, 591-593, and in NN7 (ca. 11-13 Ma ) at DSDP Site 590. Again, these sites do not have magnetostratigraphy and the ages are dependent on other nannofossil datums.

Previously, Wei and Wise (1990b) and Wei and Thierstein (1991) distinguished Reticulofenestra hesslandii from C. floridanus by the more elliptical form in the former, which is usually dominant at high latitudes. Reticulofenestra hesslandii may be synonymous with $C$. floridanus (see Firth, 1989). For purposes of this discussion, we ignore any potential taxonomic problems, treat these forms as a group and use the designation " $C$. floridanus s.l." to help make the comparison across latitudes. Consequently, the LO of $C$. floridanus s.1. falls between Samples 113-690B-5H-2, 30-32 cm, and -5H-3, 30-32 cm; between Samples 113-689B-6H-1, 30-32 cm, and $-6 \mathrm{H}-2,29-31 \mathrm{~cm}$ (Wei and Wise, 1990b); between Samples 119-744B-6H-CC and -7H-1, 110-111 cm, at Site 744 (Wei and Thierstein, 1991); between Samples 120-748B-5H-7, 10-11 $\mathrm{cm}$, and $-5 \mathrm{H}-7,58-62 \mathrm{~cm}$, at Site 748; between Samples $120-751 \mathrm{~A}-11 \mathrm{H}-6,5-7 \mathrm{~cm}$, and $-11 \mathrm{H}-7,5-7 \mathrm{~cm}$, at Site 751 ; between Samples 120-747A-7H-4, 58-62 cm, and $-7 \mathrm{H}-5$, $58-62 \mathrm{~cm}$, at Site 747 (Wei and Wise, this volume); and between Samples 114-737B-7R-1, 45-47 cm, and -7R-CC at Site 737 (Wei and Thierstein, 1991). Based on the biomagnetochronology of Gersonde et al. (1990), Harwood et al. (this volume), and Barron et al. (1991a), the LO of C. floridanus s.l. is dated as 12.3 Ma at Site 690, 12.2 Ma at Site 689, 11.1 Ma at Site $744,11.6 \mathrm{Ma}$ at Site $748,11.7 \mathrm{Ma}$ at Sites 751 and 747 , and 10.6 Ma at Site 737 (Fig. 2).

As stated previously, the sedimentation rate curves for the middle Miocene at Site 737, unlike those at other sites that have magnetostratigraphic control, were constructed by diatom and radiolarian datums only and the interval was complicated by hiatuses (Barron et al., 1991a). It is possible, therefore, that the age (10.6 Ma) assigned to the LO of C. floridanus s.l. at Site 737 has a rather large error ( $>1$ m.y.?). Data from other sites, however, show that the LO of $C$. floridanus s.l. has a relatively consistent age in the Southern Ocean (Fig. 2), ranging from 11.2 to $12.2 \mathrm{Ma}$, quite comparable with that at DSDP Site 563 in the North Atlantic (11.6 Ma; Miller et al., 1985; Parker et al., 1985). The LO of C. floridanus s.l., therefore, appears to be one of the very few Neogene nannofossil datums useful for biostratigraphy in the Southern Ocean, particularly in the extreme high latitudes.

\section{FO of Reticulofenestra perplexa}

Burns (1975) described Reticulofenestra perplexa from middle Miocene sediments at DSDP Site 265 in the southern Indian Ocean and gave the range of this species as middle to late Miocene. Haq (1976) later described Dictyococcites antarcticus from the Miocene sediments of DSDP Site 325 in the southeastern Pacific, a sequence with poor age control. Subsequently, Backman (1980) reported D. antarcticus in middle and upper Miocene sediments at DSDP Site 116 in the North Atlantic. Haq (1980) recorded D. antarcticus (R. perplexa) in the $\sim 13-5 \mathrm{Ma}$ interval (middle through late Miocene) at DSDP Site 329 in the South Atlantic. Dictyococcites antarcticus, however, is a junior synonym of $R$. perplexa (Backman in Heck, 1981; Wise, 1983; Wei, 1990).

The FO of $R$. perplexa was recognized between Samples 113-690B-4H-2, 130-132 cm, and $-4 \mathrm{H}-3,28-30 \mathrm{~cm}$; between Samples 113-689B-3H-5, 139-141 cm, and -3H-6, 29-31 cm (Wei and Wise, 1990b); between Samples 119-744B-7H-3, $110-111 \mathrm{~cm}$, and $-7 \mathrm{H}-4,110-111 \mathrm{~cm}$ (Wei and Thierstein, 1991); between Samples 120-751A-12H-6, 5-7 cm, and $-12 \mathrm{H}-7,5-7 \mathrm{~cm}$, at Site 751; between Samples 120-747A-8H-1, $58-62 \mathrm{~cm}$, and $-8 \mathrm{H}-2,10-11 \mathrm{~cm}$ (Wei and Wise, this volume); and between Samples 119-737B-7R-1, 45-47 cm, and -7R-CC (Wei and Thierstein, 1991). According to the biomagnetochronology of Gersonde et al. (1990), Barron et al. (1991a), and Harwood et al. (this volume), the FO of $R$. perplexa is at 14.3 $\mathrm{Ma}$ at Site 690, 14.2 Ma at Site 689, 12.9 Ma at Site 751, 12.4 $\mathrm{Ma}$ at Site 747, and $10.4 \mathrm{Ma}$ at Site 737 (Fig. 2). As stated above, there is a possibility that the age at Site 737 is too young due to lack of magnetostratigraphic control. Nevertheless, Figure 2 shows a rather consistent latitudinal trend of time transgression of this datum, with a younger age toward lower latitudes. Because of a major disconformity in the middle Miocene interval at Site 748, the FO of $R$. perplexa cannot be located, but it can be interpolated at around 13.0 $\mathrm{Ma}$, as suggested in Figure 2.

As Reticulofenestra perplexa is a high-latitude form that is virtually absent in the low latitudes, it is expected that the species occurred earlier in the higher latitudes. This latitudinal time transgression does not, however, eliminate the usefulness of this species datum. The data presented in Figure 2 shows a consistent trend that allows interpolation of the age of this datum at other sites in the southern high latitudes.

\section{LO of Reticulofenestra perplexa}

The LOs of $R$. perplexa were recorded at the sites under study in Samples 113-690B-4H-3, 28-30 cm, and 113-689B$3 \mathrm{H}-6,29-31 \mathrm{~cm}$ (Wei and Wise, 1990b); Samples 119-737A$19 \mathrm{X}-1,45-47 \mathrm{~cm}$, and 119-744B-3H-CC (Wei and Thierstein, 1991); and Samples 120-748B-2H-7, 58-62 cm, 120-751A$5 \mathrm{H}-6,63-65 \mathrm{~cm}$, and $120-747 \mathrm{~A}-3 \mathrm{H}-4,34-36 \mathrm{~cm}$ (Wei and Wise, this volume), and in Sample at Site 737 (Wei and Thierstein, 1991). The overlying samples at all sites except for Site 747 are either biosiliceous sediments barren of calcareous nannofossils or else delineate major disconformities. According to the biomagnetochronology of Gersonde et al. (1990), Barron et al. (1991a), and Harwood et al. (this volume), the youngest $R$. perplexa found are $10.0 \mathrm{Ma}$ in age at Site $690,8.2$ 
Ma at Site 689, 4.0 Ma at Site 744, 3.8 Ma at Site 748,6.2 Ma at Site $751,3.6 \mathrm{Ma}$ at Site 747, and 5.8 Ma at Site 737 (Fig. 2).

Figure 2 shows that the biosiliceous facies occurs drastically younger from $65^{\circ}$ to $62^{\circ} \mathrm{S}$ latitude. However, this trend does not appear to be consistent from $62^{\circ} \mathrm{S}$ to $50^{\circ} \mathrm{S}$ latitude. A similar phenomenon has been observed by Kemp et al. (1975) for a latitudinal transect drilled by DSDP Leg 28. More interestingly, Figure 2 reveals that the LO of $R$. perplexa is associated with the biosiliceous facies boundary across the latitudinal transect. Discussions on $R$. perplexa and its implication for carbonate compensation depth CCD fluctuations are presented later in the paper.

\section{BIOMETRICS}

Histograms of the size distribution of Reticulofenestra perplexa for nine samples from Site 744 are shown in Figure 3. The mean sizes for each sample are also shown and plotted vs. age. The $\sim 300$ specimens of $R$. perplexa measured in the nine samples range in size from 4.0 to $10.0 \mu \mathrm{m}$. Specimens that range in size from 5 to $8 \mu \mathrm{m}$ are most common, and the overall mean sizes range from 6.2 to $7.0 \mu \mathrm{m}$. No clear trend is apparent for the change in mean size through time.

Figure 4 shows the size distribution and mean size of $R$. perplexa for ten samples measured for Site 748. As at Site 744, most specimens of $R$. perplexa are about 5-8 $\mu \mathrm{m}$. The mean size ranges from 6.2 to $7.1 \mu \mathrm{m}$, and there is also no clear trend of change through time.

The mean sizes of $R$. perplexa at Sites 744 and 748 are plotted vs. time in Figure 5 (upper panel) to compare the differences. The figure indicates that the mean sizes are similar at both sites. Figure 5 (lower panel) also shows a comparison of the biometric results of this study with those of Backman (1980). Overall, the mean size calculated by Backman $(1980)$ is smaller $(1.0 \mu \mathrm{m})$ than that recorded in this study. Again, no clear trend of mean size change through time is apparent in the middle to late Miocene interval studied by Backman (1980). This means that mean size change of $R$. perplexa is not useful biostratigraphically within the interval from 8 to $13 \mathrm{Ma}$. It appears that the mean size change is probably controlled by factors other than pure biotic evolution.

Wei (1990) recently reexamined the topotypic material of Reticulofenestra perplexa and did a biometric study of the species in the two DSDP samples $(265-16-6,28-29 \mathrm{~cm}$, and $265-16-6,35-36 \mathrm{~cm})$. He also measured the sizes of "Dictyococcites antarcticus" in a DSDP sample $(329-3-3,30-32 \mathrm{~cm})$ from the interval in which Haq (1980) reported abundant Dictyococcites antarcticus. Results are summarized in Figure 6 . The figure shows similar size distribution patterns as those from the Kerguelen Plateau sites (Figs. 3 and 4). The biometric results and the scanning electron micrographs of Wei (1990) clearly show that the size of $R$. perplexa generally ranges from 6 to $9 \mu \mathrm{m}$ rather than $\sim 20 \mu \mathrm{m}$ as Burns (1975) and Driever (1988) claimed, and that $R$. perplexa is a senior synonym of Dictyococcites antarcticus Haq. The present study further substantiates the results of Wei (1990) by demonstrating that $R$. perplexa is a medium-sized coccolith.

\section{ABUNDANCE CHANGE OF RETICULOFENESTRA PERPLEXA RELATIVE TO COCCOLITHUS PELAGICUS}

Abundance changes of Reticulofenestra perplexa relative to Coccolithus pelagicus at six ODP sites in the Southern Ocean are shown in Figure 7. One striking feature is the similar abundance patterns at all the sites except Site 737, where the pattern appears to be out of phase compared with those of other sites. One possibility for this out of phase pattern is error in the age model constructed on siliceous microfossil datums without the constraint of magnetostratigraphy. The abundance patterns for all other sites can be generalized as shown in Figure 8. Note that the percentage of $R$. perplexa is high for the $12-10 \mathrm{Ma}$ interval. The abundance drops sharply at about $9.8 \mathrm{Ma}$, peaks around $9.6 \mathrm{Ma}$, drops again around $9.2 \mathrm{Ma}$, and rises again after 9.2 Ma. The timing of abundance fluctuations at individual sites departs from the generalized pattern only slightly, generally $<0.5 \mathrm{~m} . \mathrm{y}$. This small difference in timing may be a reflection of a diachronous timing of environmental change at different sites, but it is also very likely a result of error in the age models used.

As mentioned previously, Reticulofenestra perplexa is a cold-water end member of Miocene calcareous nannofossil assemblages and Coccolithus pelagicus represents warmer conditions in subantarctic and antarctic waters. The abundance changes of $R$. perplexa relative to $C$. pelagicus at the Southern Ocean sites (Fig. 7) can be interpreted as a reflection of surface water temperature changes. Specifically, temperature was relatively low from 12 to $10 \mathrm{Ma}$, then a warm event occurred around $10 \mathrm{Ma}$, followed by a cold event around 9.6 $\mathrm{Ma}$. Another warm event occurred around $9.2 \mathrm{Ma}$, and finally cold conditions prevailed for the rest of the late Miocene.

Currently, there are no other paleontological studies for the southern high latitudes that have enough resolution to show the temperature fluctuations for the $8-10 \mathrm{Ma}$ interval as suggested by this study. Neogene oxygen isotopic data for planktonic foraminifers from the southern high latitudes have not been available, and only isotopic data on benthic foraminifers are available for the middle and late Miocene at Site 747 (Wright and Miller, this volume). The latter data are plotted in Figure 9 (bottom) in comparison with the abundance changes of $R$. perplexa. Figure 9 shows that increases or decreases in the abundance of $R$. perplexa relative to $C$. pelagicus are generally coincident with increases or decreases in the oxygen isotopic values, respectively. This supports the above interpretation on the water temperature history. Oxygen isotope data alone, however, are ambiguous on temperature interpretations because increases or decreases in oxygen isotopic values can be caused by increases or decreases, respectively, in the volume of the ice sheet on Antarctica and by fluctuations in surface-water salinity. The latter may be influenced by changes in precipitation or the input of glacial melt-waters into the oceans as discussed by Wei and Wise (1990a).

\section{RETICULOFENESTRA PERPLEXA AND ITS IMPLICATION FOR CCD FLUCTUATIONS}

Because of its persistence (often as the only nannofossil species) in the extreme high southern latitudes as surface waters cooled during the late Miocene, Reticulofenestra perplexa stands out clearly as the cold-water end member of the Miocene nannofossil assemblages (Haq, 1980; Wise, 1983; Wei and Wise, $1990 \mathrm{~b})$. As such, and as a result of its high productivity in these cold waters, this species may have been largely responsible for the depression of the CCD and the deposition of carbonate ooze at high-latitude sites during this interval. It formed a monospecific ooze except during warmer intervals when taxa such as Coccolithus pelagicus were also present (Fig. 7).

At the extreme high latitude Maud Rise sites (689 and 690), nannofossil ooze is not continuously present but alternates with siliceous oozes. The latter facies represents the coldest intervals when surface-water temperatures fell below the tolerance limit of $R$. perplexa. The last $R$. perplexa ooze falls within the diatom Asteromphalus kennettii Zone at Site 689 and the Nitzschia praecura Zone at Site 690 , and corresponds to times of brief climatic warming as indicated by the oxygen isotopic records (Kennett and Barker, 1990). As noted in 


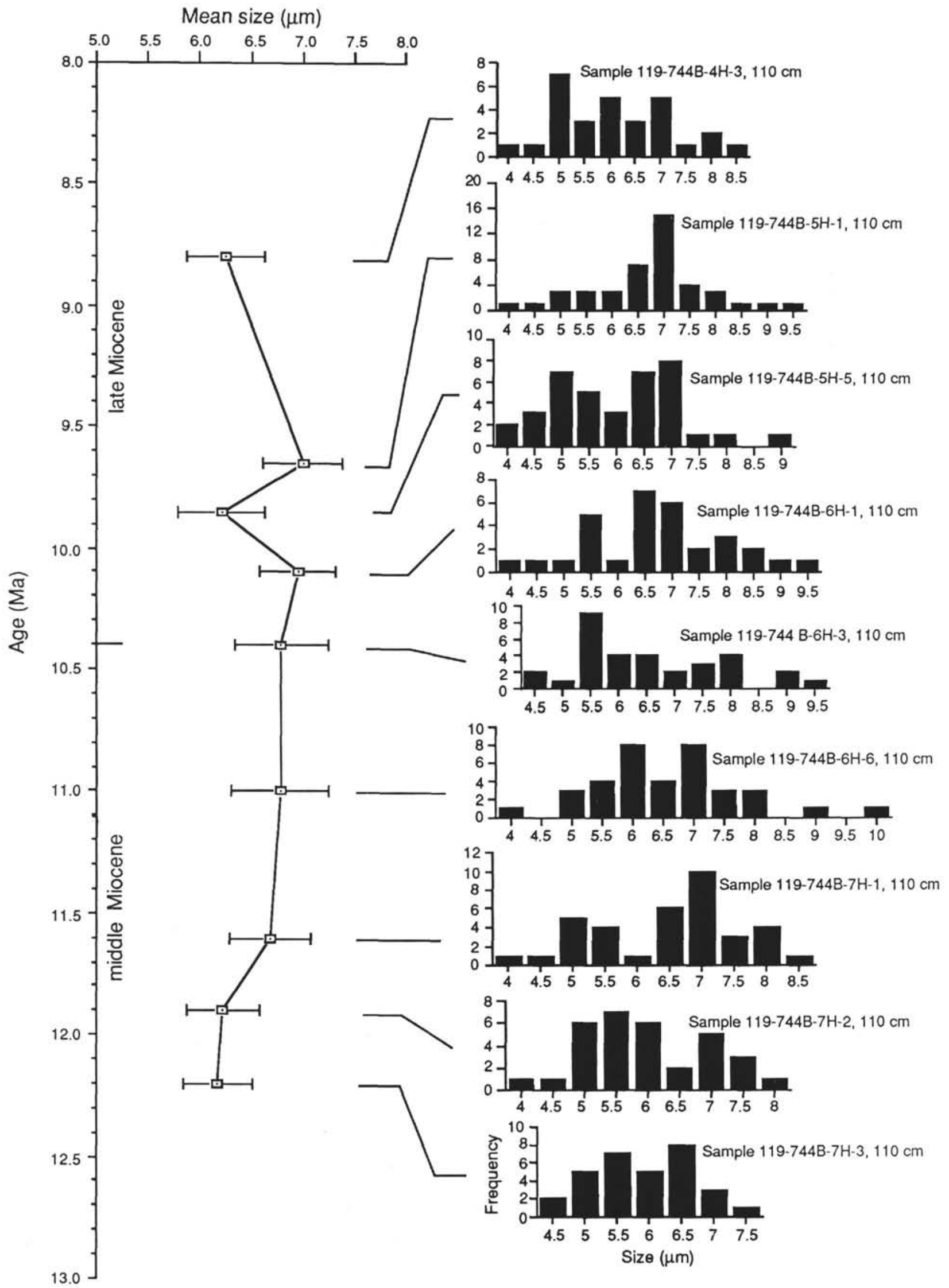

Figure 3. Histograms of size distribution and mean sizes of Reticulofenestra perplexa, Site 744 . Error bars are expressed at $95 \%$ confidence level. 
W. WEI, S. W. WISE, JR.

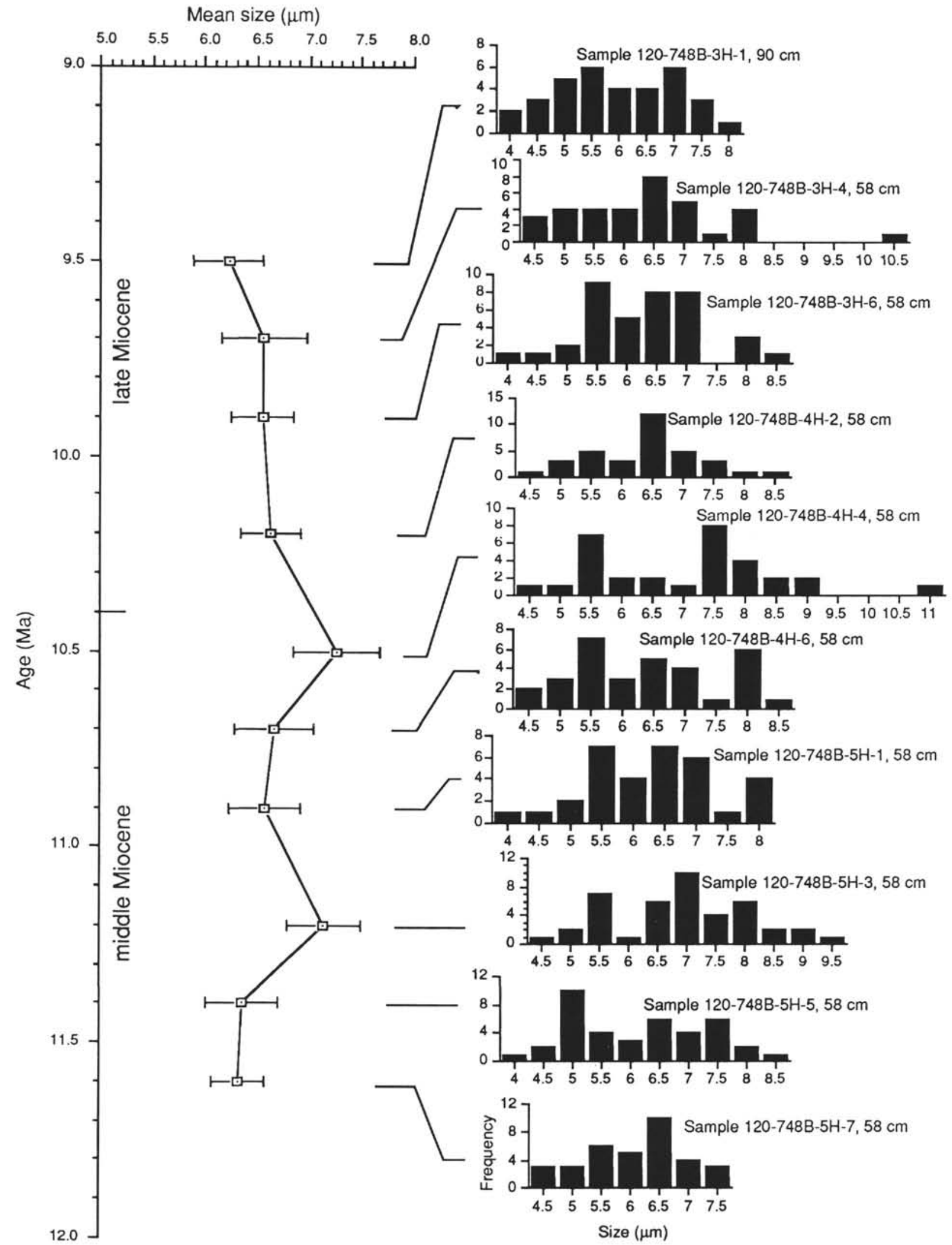

Figure 4. Histograms of size distribution and mean sizes of Reticulofenestra perplexa, Site 748 . Error bars are expressed at $95 \%$ confidence level. 


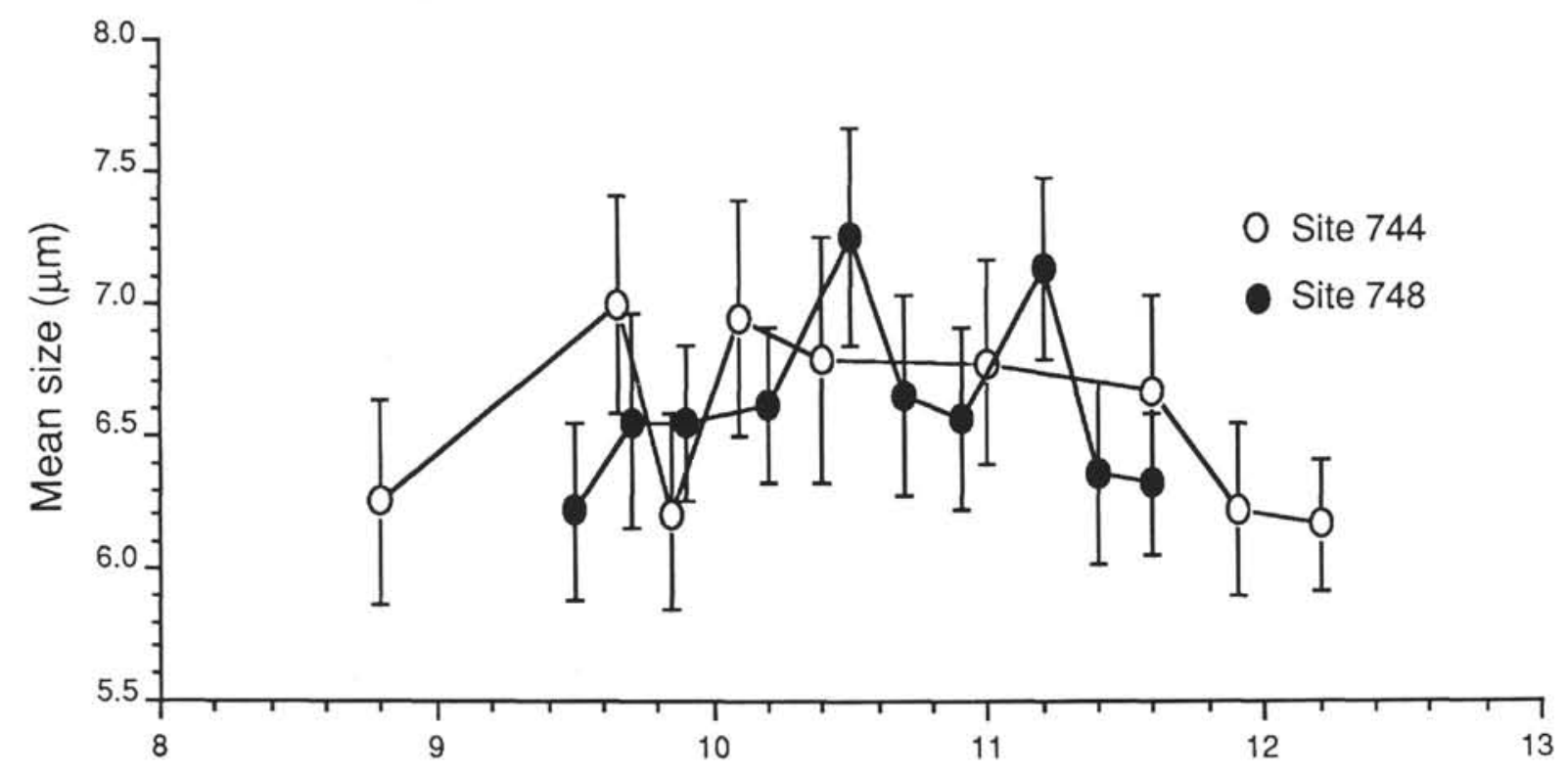

Age (Ma)

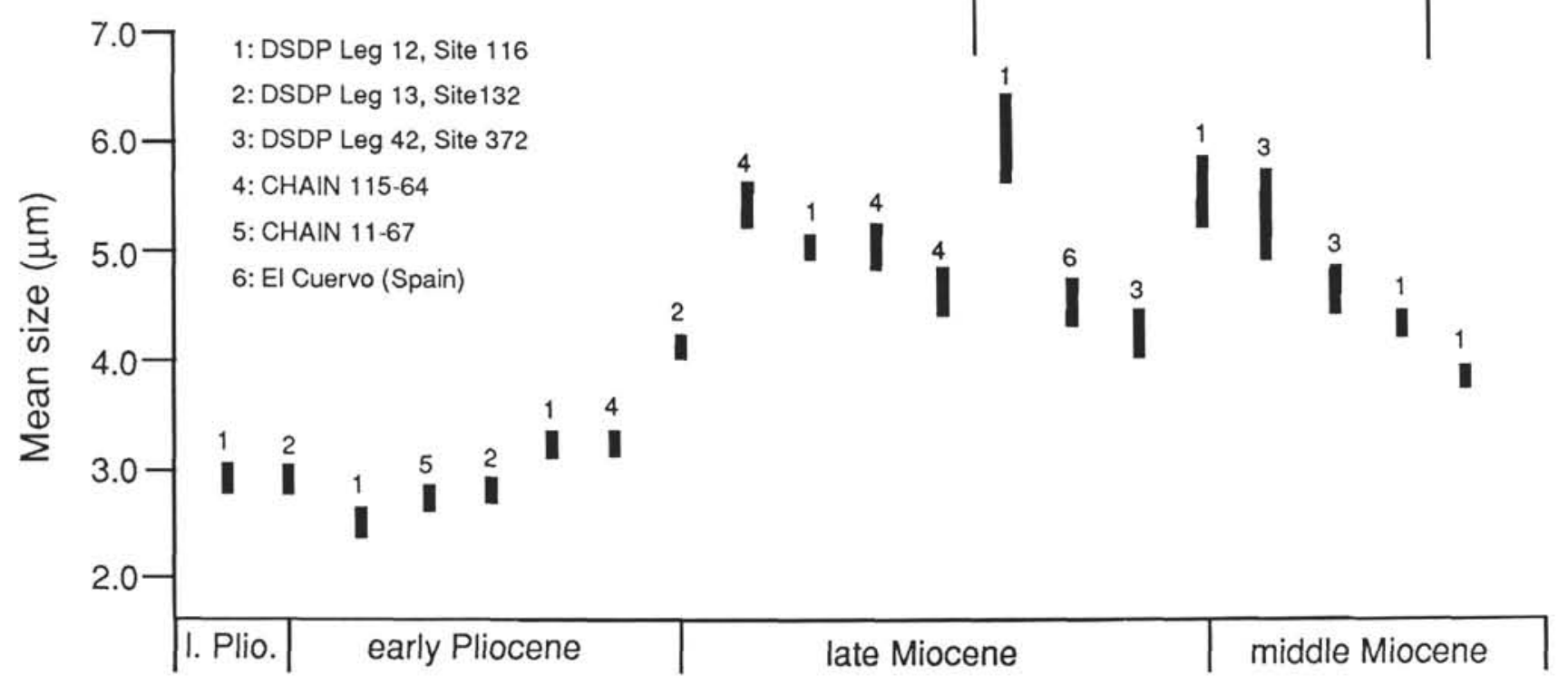

Figure 5. Comparison of mean size change of Reticulofenestra perplexa at Sites 744 and 748 and the results of Backman (1980) (lower panel). Error bars are expressed at $95 \%$ confidence level.

Figure $2, R$. perplexa disappeared at approximately $10 \mathrm{Ma}$ at Site 690, which is the deeper of the two sites on Maud Rise. Its persistence until $8.2 \mathrm{Ma}$ at the nearby, but shallower, Site 689 can be attributed to a general rise in the CCD above the level of Site 690 during the cooling that accompanied the glaciations that affected West as well as East Antarctica (Kennett, 1978). This rise in the CCD could have been a function of diminished nannoplankton productivity in the surface waters as well as the generation of colder, more corrosive deep waters, which would have promoted the dissolution of calcium carbonate.

Because of its ability to tolerate and even thrive in relatively cold surface waters, we speculate that $R$. perplexa, through its productivity, lowered the CCD and by this means, would have promoted the preservation of other calcareous microfossil species able to coexist in those waters. It was eventually driven from the extreme high latitudes during the 

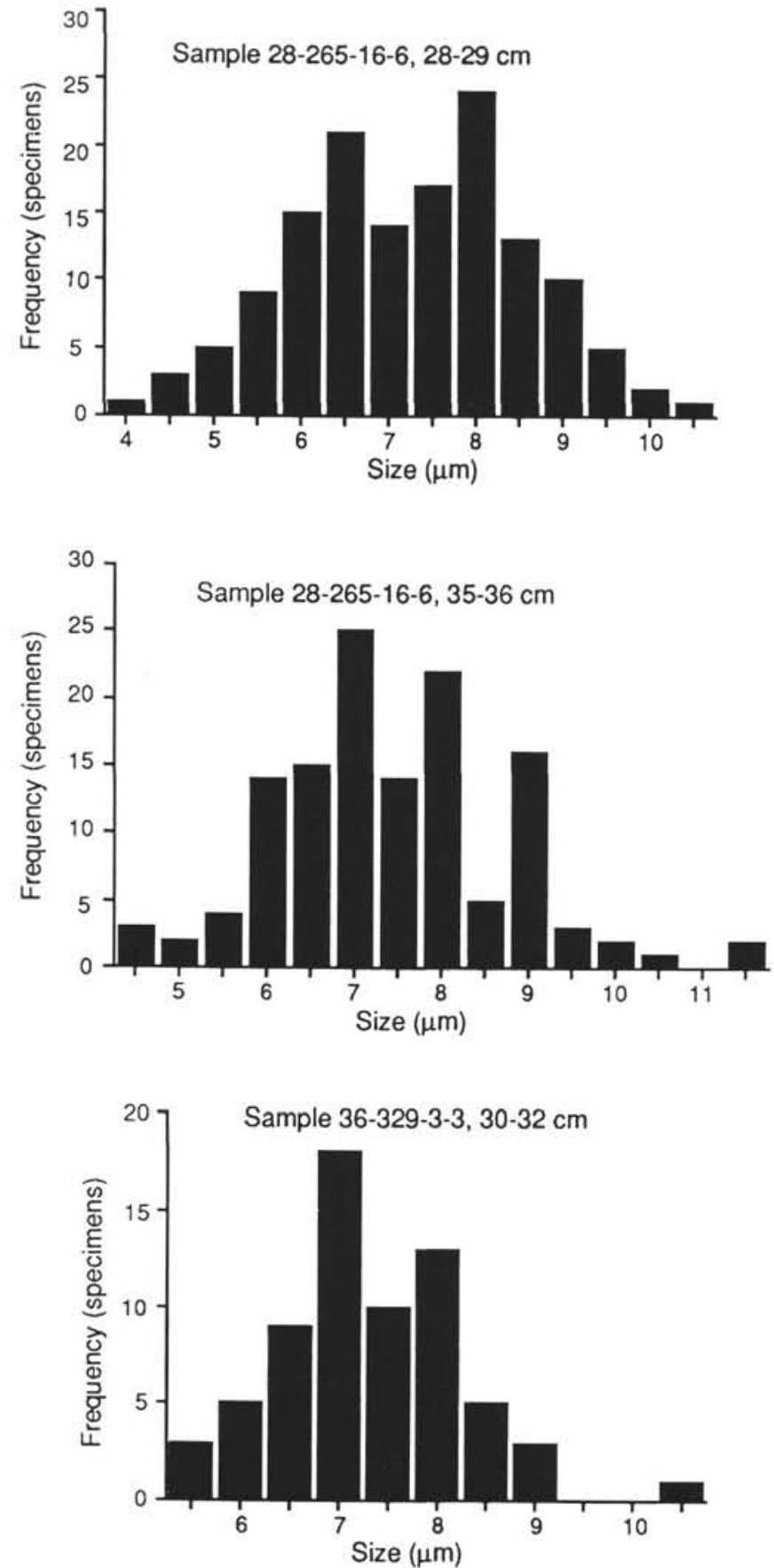

Figure 6. Histograms of size distribution of Reticulofenestra perplexa in Samples 28-265-16-6, 28-29 cm, 28-265-16-6, 35-36 cm, and 36-329-3-3, 30-32 cm (after Wei, 1990).

late Miocene glaciations of Antarctica, however, and became extinct during the earliest Pliocene. Apparently left without a cold-water-tolerant end member, calcareous nannofloras essentially vanished from Antarctic waters and nannofossil ooze deposition ceased in the highest southern latitudes during the Pliocene. Limited nannofossil ooze was deposited in higher latitudes of the subantarctic region only during brief intervals of climate amelioration. This may explain, in part, the virtual absence of nannofossils in this region during the deglacial event postulated for Antarctica during the early Pliocene by Ciesielski and Weaver (1974), Webb et al. (1984), Breza (this volume), and others. According to Barron et al. (1991b), the only significant deposition of early Pliocene nannofossils across the Kerguelen Plateau is confined to a very short interval between 4.1 and $4.2 \mathrm{Ma}$.

The establishment of a strong Polar Front Zone during the late Miocene and the development of an extremely cold Antarctic surface water mass also would have played an important role in excluding calcareous nannoplankton from the region. However, with the extinction of $R$. perplexa, the Pliocene/Pleistocene nannofloras may well have been left without a species tolerant of very cold waters until the evolution of Emiliania huxleyi during the Pleistocene (Wei and Wise, this volume). Even this taxon, however, cannot live in the extreme high southern latitudes (Wei and Wise, 1990b). Interestingly, this was not the case with the planktonic foraminifers. The late Miocene form Neogloboquadrina pachyderma developed a tolerance for extremely cold waters. Today it lives among the ice and is responsible for the deposition of a monospecific Pleistocene foraminifer ooze at Maud Rise; it is found along the Antarctic margin (Barker, Kennett, et al., 1988, and references therein).

\section{CONCLUSIONS}

The FO of Calcidiscus leptoporus/Calcidiscus macintyrei is not useful datum on Maud Rise because these taxa are rare or virtually absent. It is, however, an excellent biostratigraphic marker on the Kerguelen Plateau as it has a rather consistent age of about 18.1 Ma through a range of different latitudes (at least from $55^{\circ}$ to $62^{\circ} \mathrm{S}$ ).

Except for Site 737 , which has rather poor age control relative to the other sites studied, the LO of Cyclicargolithus floridanus s.l. at all the Southern Ocean sites examined has a fairly consistent age, ranging from 11.2 to $12.2 \mathrm{Ma}$. This age is quite comparable with the one determined at DSDP Site 563 in the North Atlantic (11.6 Ma, Miller et al., 1985; Parker et al., 1985). This is one of the very few biostratigraphically useful Neogene datums in the Southern Ocean.

The FO of Reticulofenestra perplexa is shown to be latitudinally time transgressive. It has an age of $14.3 \mathrm{Ma}$ at $65^{\circ} \mathrm{S}$, becomes progressively younger toward the lower latitudes, and has an age of $12.3 \mathrm{Ma}$ at $55^{\circ} \mathrm{S}$. This trend of younger ages toward lower latitudes is, however, rather consistent. Thus, the age vs. latitude curve established in this study allows one to make useful predictions on the age of this species datum at different latitudes of the Southern Ocean.

The LO of Reticulofenestra perplexa generally coincides with the LO of calcareous nannofossils in Miocene sediments of the southern high latitudes. This level generally becomes younger toward the lower latitudes, but not all of the data are consistent with this trend.

The biometric study of Reticulofenestra perplexa for Sites 744 and 748 on the Kerguelen Plateau shows that most specimens range from 5 to $8 \mu \mathrm{m}$ in size (length), similar to those of the topotypic material of $R$. perplexa from DSDP Site 265 (Wei, 1990). The mean size change of the species through time in the 13-8 Ma interval is not useful stratigraphically because there is no clear trend in the data.

The patterns of abundance changes of Reticulofenestra perplexa relative to Coccolithus pelagicus are generally similar at the southern high-latitude sites. The abundance was high (near $100 \%$ ) for the 12-10 Ma interval, and it fluctuates greatly in the 10-8 Ma interval. These fluctuations can be interpreted as reflections of alternating warm and cool events during that time interval.

Because of its ability to tolerate and even thrive in cold surface waters, $R$. perplexa significantly influenced the position of the CCD in the Southern Ocean during the Miocene. 

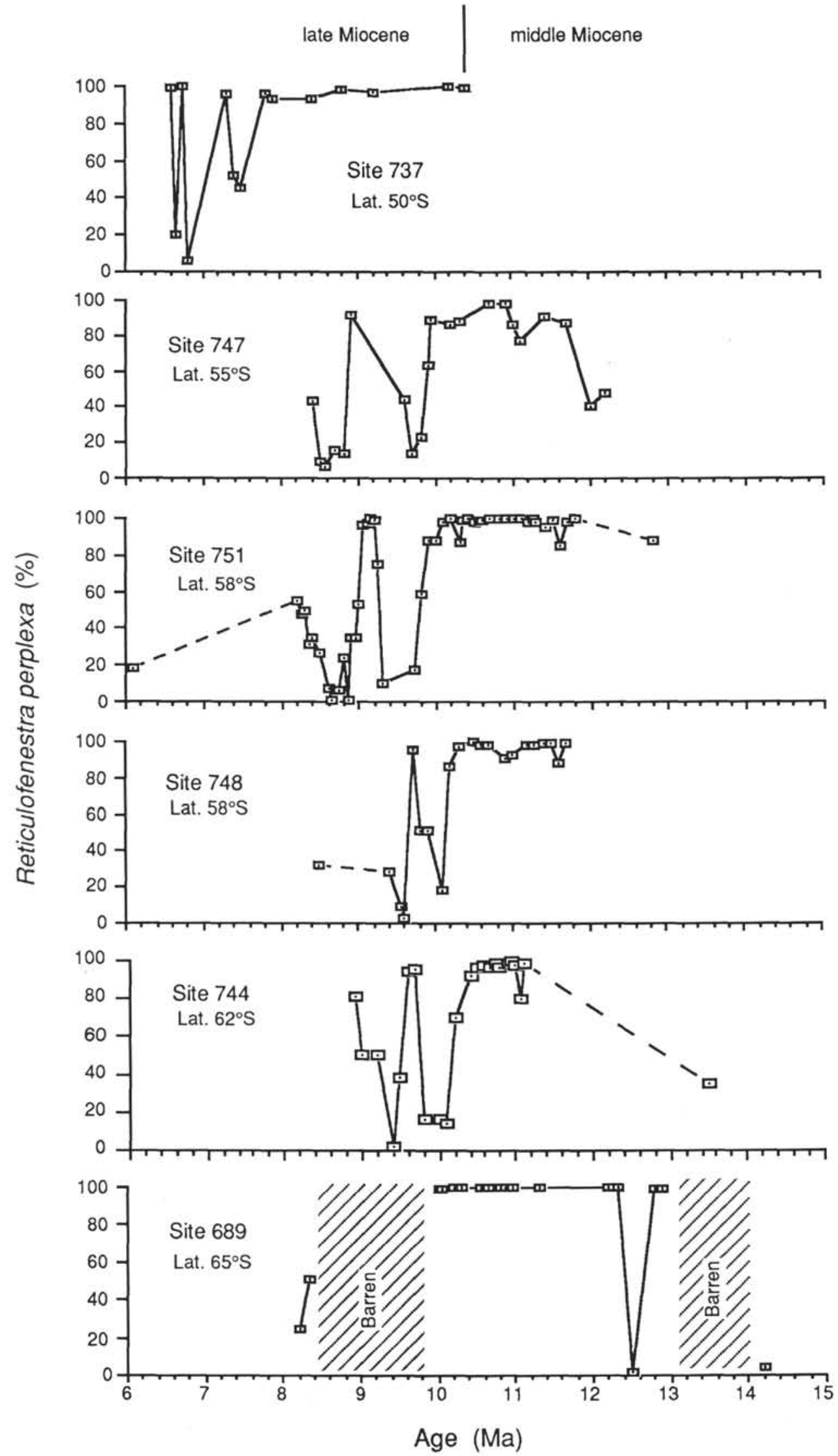

Figure 7. Abundance change of Reticulofenestra perplexa relative to Coccolithus pelagicus at six ODP sites in the Southern Ocean (arranged according to latitude). 


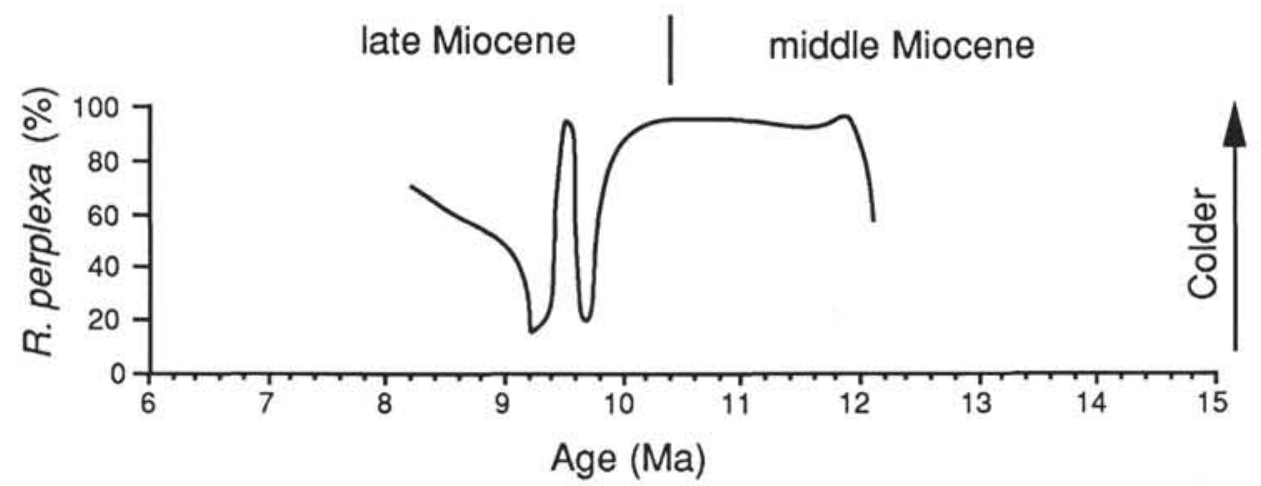

Figure 8. Generalized model of abundance change of Reticulofenestra perplexa relative to Coccolithus pelagicus in the Southern Ocean. The higher the abundance of $R$. perplexa, the colder the water inferred.

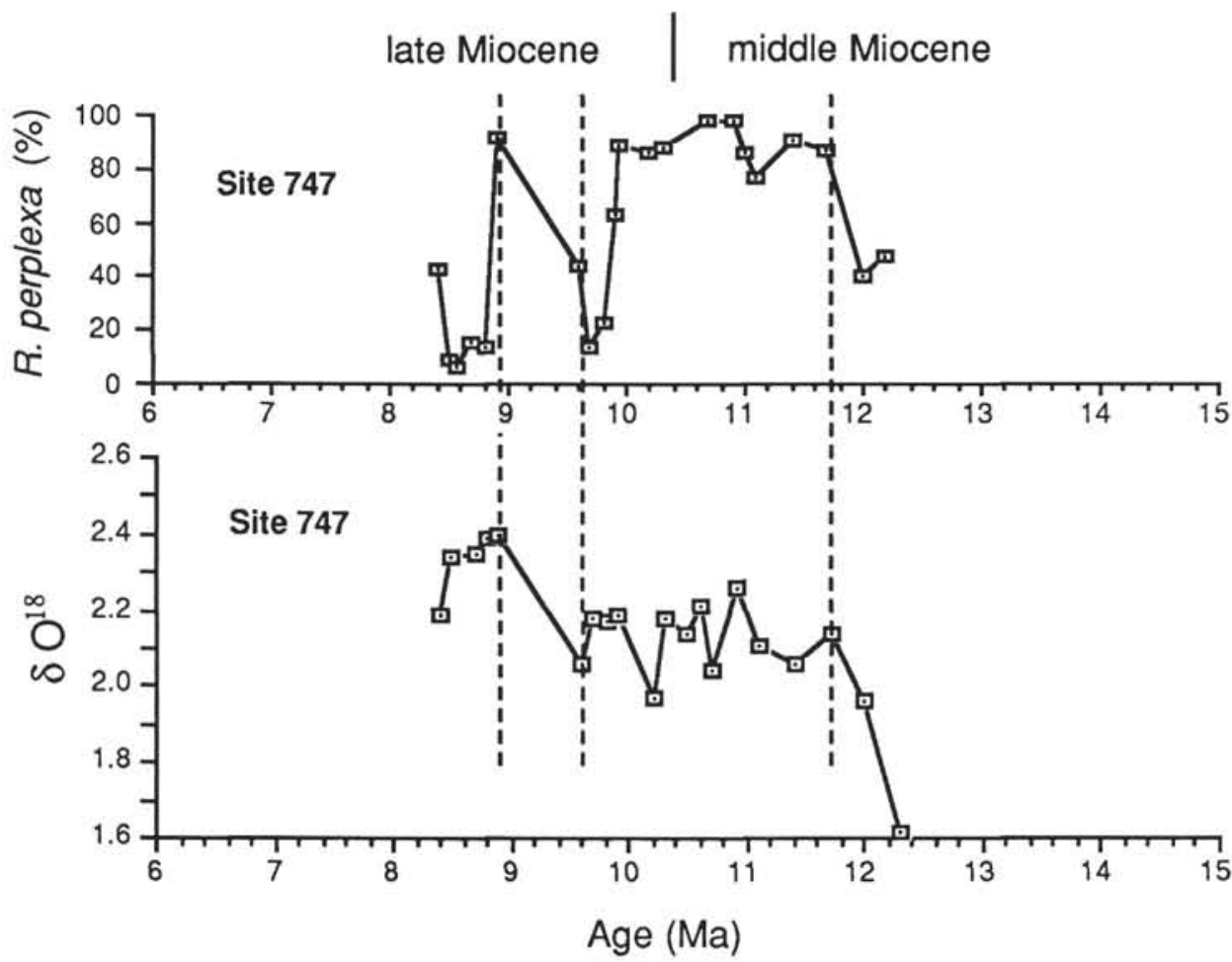

Figure 9. Comparison of the abundance change of Reticulofenestra perplexa relative to Coccolithus pelagicus with the change of oxygen isotopic values of benthic foraminifers (Wright and Miller, this volume) at Site 747 . Note that the increase or decrease in the $R$. perplexa abundance is generally coincident with the increase or decrease in the isotope values, respectively (indicated by dashed lines).

The disappearance of this species, combined with the establishment of the Polar Front Zone during the late Mioceneearly Pliocene glaciations of East and West Antarctica, apparently left the high-latitude Southern Ocean virtually devoid of nannofossil ooze deposition during the Pliocene/Pleistocene.

\section{ACKNOWLEDGMENTS}

We thank Dr. T. J. Bralower and an anonymous reviewer for thorough critical reviews. Samples were provided by the Ocean Drilling Program. This study was supported by an equipment grant from the Amoco Foundation, USSAC grants, and NSF Grant No. DPP89-17976.

\section{REFERENCES}

Backman, J., 1980. Miocene-Pliocene nannofossils and sedimentation rates in the Hatton-Rockall Basin, NE Atlantic Ocean. Stockholm Contrib. Geol., 36:1-91.

Barker, P. F., Kennett, J. P., et al., 1988. Proc. ODP, Init. Repts., 113: College Station, TX (Ocean Drilling Program).

Barron, J., Baldauf, J. G., Barrera, E., Caulet, J.-P., Huber, B. T., Keating, B. H., Lazarus, D., Sakai, H., Thierstein, H. R., and Wei, W., 1991a. Biochronologic and magnetochronologic synthesis of ODP Leg 119 sediments from the Kerguelen Plateau and Prydz Bay, Antarctica. In Barron, J., Larsen, B., et al., Proc. ODP, Sci. Results, 119: College Station, TX (Ocean Drilling Program), 813-848. 
Barron, J., Larsen, B., and Baldauf, J. G., 1991b. Evidence for late Eocene-early Oligocene Antarctic glaciation and observations on late Neogene glacial history of Antarctica: results from ODP Leg 119. In Barron, J., Larsen, B., et al., Proc. ODP, Sci. Results, 119: College Station, TX (Ocean Drilling Program), 869-894.

Berggren, W. A., Kent, D. V., and Van Couvering, J. A., 1985. The Neogene: Part 2. Neogene geochronology and chronostratigraphy. In Snelling, N. J. (Ed.), The Chronology of the Geological Record. Geol. Soc. London Mem., 10:211-260.

Burns, D. A., 1975. Distribution, abundance, and preservation of nannofossils in Eocene to Recent Antarctic sediments. N. Z. J. Geol. Geophys., 18:583-595.

Ciesielski, P. F., and Weaver, F. M., 1974. Early temperature changes in the Antarctic Seas. Geology, 2:511-515.

Driever, B., 1988. The size of the coccoliths of Dictyococcites perplexa Burns. INA Newsl., 10:89.

Firth, J., 1989. Biometric study of Eocene-Oligocene calcareous nannofossils [Ph.D. dissert.]. Florida State Univ., Tallahassee.

Gard, G., 1988. Late Quaternary calcareous nannofossil biochronology and paleo-oceanography of Arctic and subarctic seas [Ph.D. dissert.]. Stockholm Univ., Stockholm.

Geitzenauer, K. R., 1969. Coccoliths as late Quaternary paleoclimatic indicators in the subantarctic Pacific Ocean. Nature, 223:170-172.

Gersonde, R., Abelmann, A., Burckle, L. H., Hamilton, N., Lazarus, D., McCartney, K., O'Brien, P., Spieß, V., and Wise, S. W., Jr., 1990. Biostratigraphic synthesis of Neogene siliceous microfossils from the Antarctic Ocean, ODP Leg 113 (Weddell Sea). In Barker, P. F., Kennett, J. P., et al., Proc. ODP, Sci. Results, 113: College Station, TX (Ocean Drilling Program), 915-936.

Haq, B. U., 1976. Coccoliths in cores from the Bellingshausen abyssal plain and Antarctic continental rise. In Hollister, C. D., Craddock, C., et al., Init. Repts. DSDP, 35: Washington (U.S. Govt. Printing Office), 557-567.

1980. Biogeographic history of Miocene calcareous nannoplankton and paleoceanography of the Atlantic Ocean. Micropaleontology, 26:414-443.

Haq, B. U., and Lohmann, G. P., 1976. Early Cenozoic calcareous nannoplankton biogeography of the Atlantic Ocean. Mar. Micropaleontol., 1:119-194.

Haq, B. U., Premoli-Silva, I., and Lohmann, G. P., 1977. Calcareous plankton paleobiogeographic evidence for major climatic fluctuations in the early Cenozoic Atlantic Ocean. J. Geophys. Res. $82: 3861-3876$.

Kemp, E. M., Frakes, L. A., and Hays, D. E., 1975. Paleoclimatic significance of diachronous biogenic facies, Leg 28, Deep Sea Drilling Project. In Hays, D. E., Frakes, L. A., et al., Init. Repts. DSDP, 28: Washington (U.S. Govt. Printing Office), 909-917.

Kennett, J. P., 1978. The development of planktonic biogeography in the Southern Ocean during the Cenozoic. Mar. Micropaleontol., $3: 301-345$.

Kennett, J. P., and Barker, P. F., 1990. Latest Cretaceous to Cenozoic climate and oceanographic developments in the Weddell Sea, Antarctica: an ocean-drilling perspective. In Barker, P. F., Kennett, J. P., et al., Proc. ODP, Sci. Results, 113: College Station, TX (Ocean Drilling Program), 937-960.

Khan, M. J., Kent, D. V., and Miller, K. G., 1985. Magnetostratigraphy of Oligocene to Pleistocene sediments, Sites 558 and 563. In Bougault, H., Cande, S. C., et al., Init. Repts. DSDP, 82: Washington (U.S. Govt. Printing Office), 385-392.

Knappertsbusch, M., 1989. Morphological evolution of the Neogene coccolith group Calcidiscus leptoporus-Calcidiscus macintyrei. INA Newsl., 11:74-75.

Knüttel, S., 1986. Calcareous nannofossil biostratigraphy of the Central East Pacific Rise, Deep Sea Drilling Project Leg 92: evidence for downslope transport of sediments. In Leinen, M., Rea, D. K., et al. Init. Repts. DSDP, 92: Washington (U.S. Govt. Printing Office), 255-290.

Lohmann, W. H., 1986. Calcareous nannoplankton biostratigraphy of the southern Coral Sea, Tasman Sea, and southwestern Pacific Ocean, Deep Sea Drilling Project Leg 90: Neogene and Quaternary. In Kennett, J. P., von der Borch, C. C., et al., Init. Repts. DSDP, 90: Washington (U.S. Govt. Printing Office), 763-793.
Martini, E., and Müller, C., 1986. Current Tertiary and Quaternary calcareous nannoplankton stratigraphy and correlations. Newsl. Stratigr., 16:99-112.

McClave, J. T., and Dietrich, F. H., II., 1982. Statistics. Santa Clara, CA (Dellen Pub. Co.).

McIntyre, A., 1967. Coccoliths as paleoclimatic indicators of Pleistocene glaciation. Science, 158:1314-1317.

McIntyre, A., and Bé, A.W.H., 1967. Modern Coccolithophoridae of the Atlantic Ocean. I: placoliths and cyrtoliths. Deep-Sea Res. Oceanogr. Abstr., 14:561-597.

McIntyre, A., Bé, A.W.H., and Roche, M. B., 1970. Modern Pacific Coccolithoporida: a paleontological thermometer. Trans. N. Y. Acad. Sci., 32:720-731.

Miller, K. G., Aubry, M.-P., Khan, M. J., Melillo, A. J., Kent, D. V., and Berggren, W. A., 1985. Oligocene-Miocene biostratigraphy, magnetostratigraphy, and isotopic stratigraphy of the western North Atlantic. Geology, 13:257-261.

Okada, H., and Bukry, D., 1980. Supplementary modification and introduction of code numbers to the low-latitude coccolith biostratigraphic zonation (Bukry 1973; 1975). Mar. Micropaleontol., 5:321-325.

Parker, M. E., Clark, M., and Wise, S. W., Jr., 1985. Calcareous nannofossils of Deep Sea Drilling Project Sites 558 and 563, North Atlantic Ocean: biostratigraphy and the distribution of Oligocene braarudosphaerids. In Bougault, H., Cande, S. C., et al., Init. Repts. DSDP, 82: Washington (U.S. Govt. Printing Office), 559589.

Perch-Nielsen, K., 1985. Cenozoic calcareous nannofossils. In Bolli, H. M., Saunders, J. B., and Perch-Nielsen, K. (Eds.), Plankton Stratigraphy: Cambridge (Cambridge Univ. Press), 427-554.

Raffi, I., and Rio, D., 1981. Coccolithus pelagicus (Wallich): a paleotemperature indicator in the late Pliocene Mediterranean deep sea record. In Wezel, F. C. (Ed.), Sedimentary Basins of Mediterranean Margins. C.N.R. Italian Project of Oceanography, Bologna (Tecnoprint), 187-190.

Roth, P. H., and Krumbach, K. R., 1986. Middle Cretaceous calcareous nannoplankton biogeography and preservation in the Atlantic and Indian Oceans: implications for paleoceanography. Mar. Micropaleontol., 10:235-266.

Siesser, W. G., and Haq, B. U., 1987. Calcareous nannoplankton. In Broadhead, T. W. (Ed.), Fossil Prokaryotes and Protists: Notes for a Short Course. Univ. of Tennessee Dept. of Geol. Sci., Studies in Geology, 18:87-127.

van Heck, S. E., 1981. Bibliography and taxa of calcareous nannoplankton. INA Newsl., 3:4-41.

Webb, P. N., Harwood, D. M., McKelvey, B. C., Mercer, J. H., and Stott, L. D., 1984. Cenozoic marine sedimentation and ice-volume variation on the East Antarctic craton. Geology, 12:287-291.

Wei, W., 1990. Clarification of Reticulofenestra perplexa (Burns) Wise, 1983. INA Newsl., 13:14-16.

Wei, W, and Thierstein, H. R., 1991. Upper Cretaceous and Cenozoic calcareous nannofossils of the Kerguelen Plateau (southern Indian Ocean) and Prydz Bay (East Antarctica). In Barron, J., Larsen, B., et al., Proc. ODP, Sci. Results, 119: College Station, TX (Ocean Drilling Program), 467-492.

Wei, W. and Wise, S. W., Jr, 1990a. Middle Eocene-Oligocene calcareous nannoplankton biogeographic gradient of the South Atlantic Ocean. Palaeogeogr., Palaeoclimatol., Palaeoecol., 79:29-61.

$1990 \mathrm{~b}$. Middle Eocene to Pleistocene calcareous nannofossils recovered by ODP Leg 113 in the Weddell Sea. In Barker, P. F., Kennett, J. P., et al., Proc. ODP, Sci. Results, 113: College Station, TX (Ocean Drilling Program), 639-666.

Wise, S. W., Jr., 1983. Mesozoic and Cenozoic calcareous nannofossils recovered by Deep Sea Drilling Project Leg 71 in the Falkland Plateau region, Southwest Atlantic Ocean. In Ludwig, W. J., Krasheninnikov, V. A., et al., Init. Repts. DSDP, 71, Pt. 2 Washington (U.S. Govt. Printing Office), 481-550.

Date of initial receipt: 7 May 1990

Date of acceptance: 13 November 1990

Ms 120B-182 

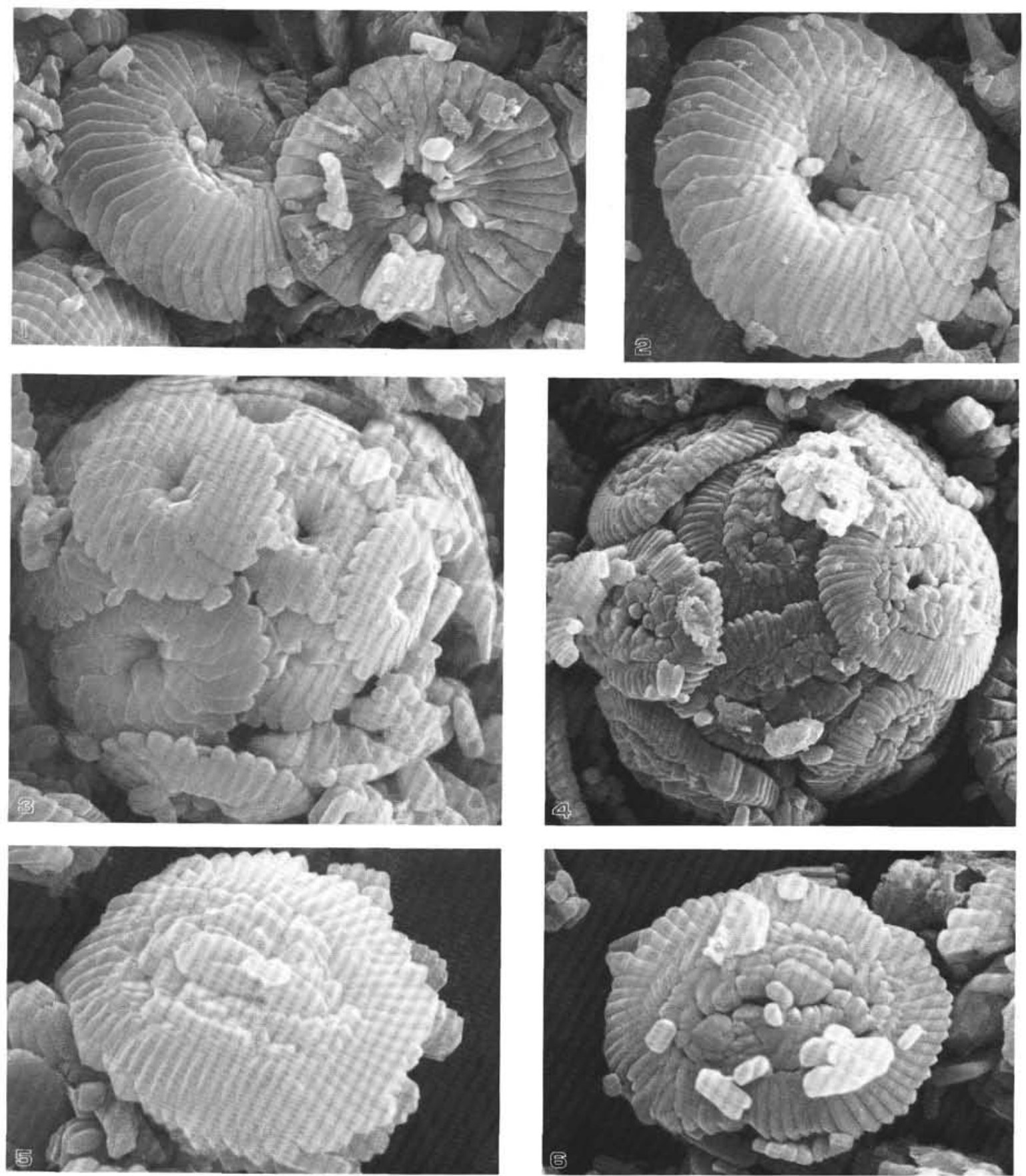

Plate 1. 1, 2. Calcidiscus macintyrei (Bukry and Bramlette) Loeblich and Tappan. (1) Distal view on left, proximal view on right; magnification $=\times 6,000$; Sample 119-744B-5H-6, $110-111 \mathrm{~cm}$; $(2)$ distal view; $\times 7,500$; Sample 119-744B-5H-6, $110-111 \mathrm{~cm}$. 3. Coccosphere of Calcidiscus leptoporus (Murray and Blackman) Loeblich and Tappan; $\times 8,000 ;$ Sample 120-747A-6H, 58-62 cm. 4-6. Reticulofenestra perplexa (Burns) Wise, Sample 28-265-16-6, 28-29 cm. (4) Coccosphere, $\times 5,500 ;(5) \times 9,500 ;(6) \times 7,000$. 

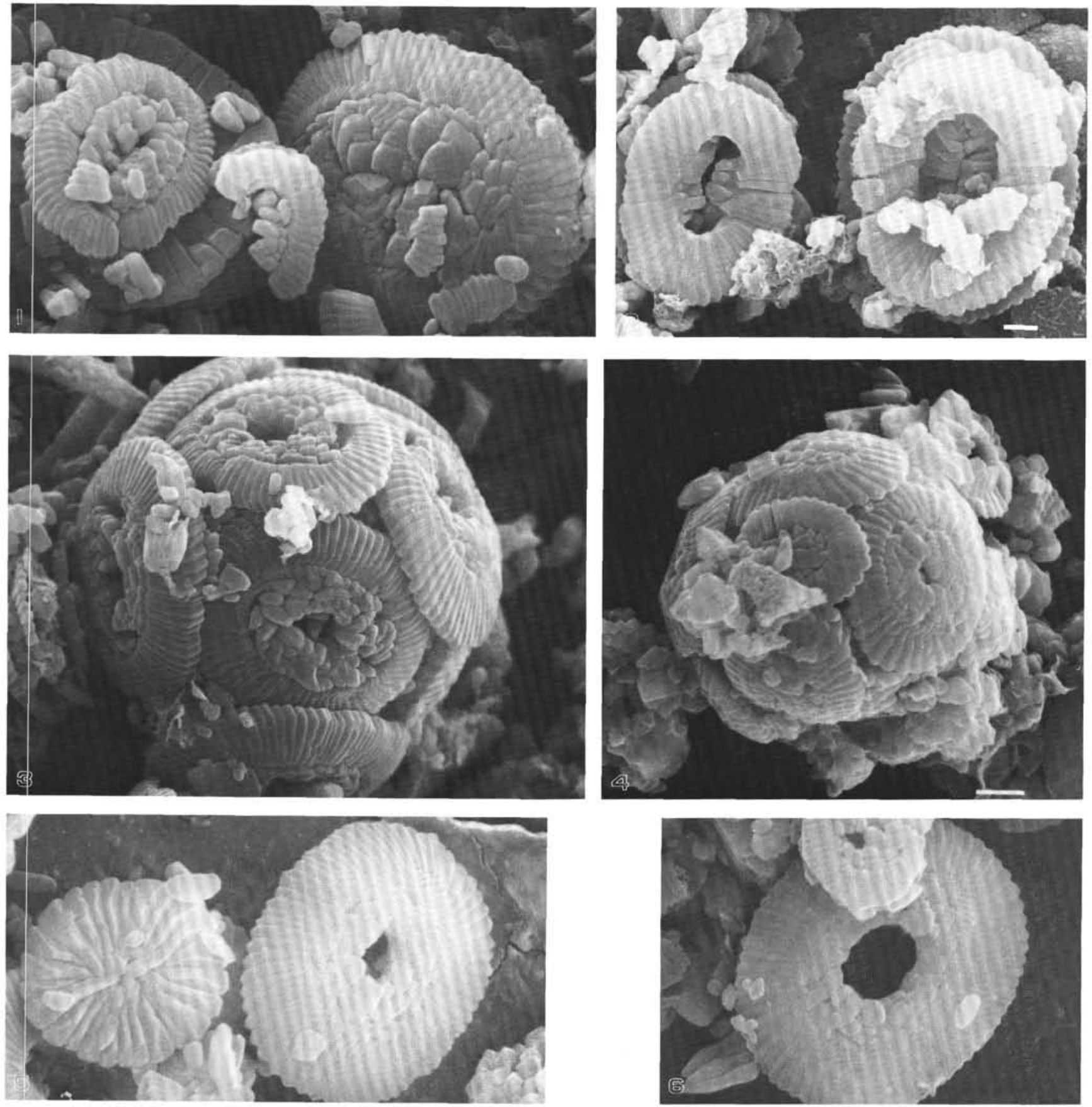

Plate 2. 1-3. Reticulofenestra perplexa (Burns) Wise. (1) Distal views of two specimens; note the size variation; $\times 6,500$; Sample $119-744 \mathrm{~B}-4 \mathrm{H}-3,110-111 \mathrm{~cm}$; (2) proximal views of two specimens; note the size variation; $\times 5,500$; Sample $119-744 \mathrm{~B}-4 \mathrm{H}-3,110-111 \mathrm{~cm}$; (3) coccosphere, $\times 5,500$, Sample 28-265-16-6, 28-29 cm. 4. Coccosphere of Cyclicargolithus floridanus (Roth and Hay) Bukry; $\times 5,000$; Sample 119-744B-8H-4, 110-111 cm. 5. Overgrown specimen of Calcidiscus leptoporus(?) on left; Reticulofenestra gelida (Geitzenauer) Backman on right; $\times 6,500$; Sample 119-744B-5H-2, 110-111 cm. 6. Reticulofenestra gelida (Geitzenauer) Backman; $\times 7,000 ;$ Sample $120-747$ A-7H-6, $58-62 \mathrm{~cm}$. 